\title{
Education Strategy of Professional Physical Education Talents' Practical Ability Cultivation under the New Situation
}

\author{
ChangSha Li \\ Institute of Physical Education, Longyan University, Longyan, Fujian, CHINA \\ ShanYe Lai \\ Institute of Physical Education, Longyan University, Longyan 364012, Fujian, CHINA
}

Received 15 June 2017 • Revised 17 September 2017 • Accepted 1 October 2017

\begin{abstract}
Objective: Education undergoes constantly reform and school education also constantly makes progress, however, presently many schools have omissions in fostering students' practical ability, causing extremes in polarization of theory and practice after graduating. Practical ability is an important ability in physical education major, and so its cultivation study is very necessary. Research method: in this paper, literature consultation, questionnaire survey, mathematical statistics, logistic analysis and interviewing are applied to investigate systematically on fostering our school's physical education major students' practical ability from Grade 2013 to 2016. Research process: Finding issues in students' cultivation process through parsing how school fosters practical ability of students in physical education major, what about students' mastering level on practical ability, and then making analysis of the issues and putting forward suggestions. Result shows that students in physical education major are weak in practical ability, with a main reflection of general practical ability, physical education ability, sports race organization ability, extracurricular activity ability, sports training ability and scientific research ability. Suggestions: We should strengthen sports knowledge and skills' practical teaching, organization on sports race, construction of external-campus practice base, guidance on working out thesis; school should make proper adjustment on physical education talents cultivation plan in accordance with realistic social conditions.
\end{abstract}

Keywords: physical education, practice ability cultivation, teaching method, training channel, education strategy

\section{INTRODUCTION}

Education undergoes constantly reform and school education also constantly makes progress, however, presently many schools have omissions in fostering students' practical ability, causing extremes in polarization of theory and practice after graduating and they couldn't enter the work state very well and very quickly. Sports are a special discipline, and one should firstly possess good sports technology and teaching ability to become a qualified sports teacher (Zhou et al., 2012). However, there are many problems in many physical education normal college graduates' practical ability, for instance, some students have rich theoretical knowledge but their sports skills are weak, they are speakers rather than doers; some students have good sports skills but lack of theoretical knowledge reservation, they are doers rather than speakers (Li et al., 2016). With regard to this, how to well organize students and foster their practical ability has become an important topic in social research.

(C) Authors. Terms and conditions of Creative Commons Attribution 4.0 International (CC BY 4.0) apply. Correspondence: ChangSha Li, Institute of Physical Education, Longyan University, Longyan 364012, Fujian, China. 


\section{Contribution of this paper to the literature}

- This paper, from schools' talents cultivation plan, studies on current status of students' practical ability. Through analysis, it puts forwards relevant suggestions and conclusions to improve students' practical ability step by step and go deeper into studying.

- Students in physical education major shows an increasing trend in various practical ability as they upgrades, from which they have higher physical education ability, exercise training ability and organizing ability of sports race, lower organization and management ability and extracurricular activity organization in the terms of general practical ability, and they should improve scientific research ability.

- Undergraduate students' practical ability should be promoted from four aspects, such as fostering students' practical ability in sports knowledge and sports skill teaching, organization ability of sports race, construction of external-campus practice base and guidance on scientific and research ability.

With increasingly development of society and reform of economy and politics, modern society has become a society of talents competition, whereas the key to the competition lies on that of practical ability. So does sports. As one of the ancient courses in sports history, physical education, focus on stronger practical ability. Research on fostering practical ability is very necessary (Chen \& Zhang, 2016).

i) Practical ability is one of important abilities in physical education, and physical education course has specialty -"practice" that other disciplines don't possess, so it becomes crucial. However, it shows weak and has many shortcomings in many physical education major's students now.

ii) Presently, rarely and even no scholars have put forward specific plans to improve students' practical ability. In this paper, it takes physical institutes as examples, starts from talents cultivation plan thereof, researches on students' practical ability status and puts forward relative suggestions and conclusions step by step and goes into deeper studying by analysis.

iii) There is a long history in school physical education. Taking schools with most rich teaching experiences as examples, we parse how present physical education institute fosters practical ability of students in physical education major and explore more typical and referential cultivation of students' practical ability.

\section{RESEARCH STATUS SUMMARIES}

\section{Relevant Research on Education Practical Ability}

In Marxist Philosophy, it defines practical ability as "ability that individual may or can fulfill special practical activities". Weili Fu and Lei Liu defined practical ability as the total sum of these physiological and psychological characteristics that individual possesses to handle with practical problems smoothly using existing knowledge and skills (Zhang \& Peng, 2017). As far as students are concerned, the ability refers to students adapt to social life with knowledge that they learnt and solve problems so that facilitate personal growth, which cannot be measured by test paper scores but evaluated by practical abilities. In Discussing on strengthening the importance of fostering university students' professional practical ability", Feifei Hao suggested that professional practical ability referred to the scope of abilities that using relevant theoretical knowledge to solve a special problem consciously, purposely and systematically based on special subjects in some studies, including ability of analyzing information, logical thinking, information handling, exploration and research, etc. Yongcheng Tao, Ye Peng, Bangyao Zhou thought that professional practical ability indeed was to let university students to take some personal activities as observation, learning, investigation and operation when they engaged in industries relevant to their major after graduation. To sum up, practical ability refers to "ability that individual can solve practical problems" for short (Zhang \& Qin, 2016). 


\section{Constitute Research of Physical Education Practical Ability}

As a future sports teacher, students in physical education major's practical ability directly related to quality of education in the future. What on earth parts compose of practical ability was explored deeply by Chinese researchers (Zhang, 2017).

Regarding the problem of which parts essentially compose of practical ability of students in physical education major, there are various opinions. Kuang Li and other scholars thought that their practical ability could be divided into general ability and special ability. Among them, general ability contains operability, language organization ability and intelligence so on, while special ability contains education ability, interpersonal communication ability and students' management ability and so on. Zuoyun Zhou etc. suggested that practical ability of physical education students could be divided into education ability, teaching ability and ability of creating good situation. Among them, education ability covers appeal to students in class, individualized education ability and ability of handling with students' emotions. Teaching talents contain ability of organizing and using textbooks, language expression ability and classroom organization ability so on. Analyzing from psychology, practical ability of students in physical education major is composed of general ability and special ability, from which special ability contains classroom teaching ability, class management ability, and classroom supervising ability and ability that is conductive to promote personal cognitive level and teaching practices as well as innovative ability and so on. Students in physical education major are practitioners that really engage in teaching practices in teaching sites, instead of observers or listeners. It is very necessary to effectively train and promote teaching practicability of students in physical education major (Li et al., 2017). Ru Wan and Zhenming Mao thought that sports practical ability covered four aspects, capable of exercising, able to appreciate sports, working hard in physical exercises, and taking relaxation activity by applying sports. As future sports teachers, students in physical education major should firstly master relevant theoretical knowledge, and then be capable of teaching. Next they should formulate effective and proper training plan and organize and judge a competition in accordance with students' basic information and social environment; and finally they should possess scientific research ability and so on (Liu, 2013). Deng Yun thought that as future sports teachers, students in physical education major should not only possess common ability as other disciplinary teachers, but also be capable of organizing extracurricular activities since the activities are important parts of students' school life, occupying rather larger time. As future sports teachers, students in physical education major should firstly have firm devoting spirit and sense of social responsibility; secondly, they should be able to give a good physical education lesson; and then they should do a good job in school sports activities, finally they should impart knowledge and educate people, taking care of students' sound growth in an all-around way (Zhang \& QIN, 2012). Shigao Chen ranked sports professionals' abilities according to importance, he suppose that a sports teacher should firstly possess teaching ability, next is ability of organizing sports training and handling with interpersonal communication. Besides, they should master ability of class management and language expression as well as innovation.

To sum up, we can conclude that practical ability of students in physical education major should contain teaching ability, expression ability, class management ability, scientific research ability, lifelong learning ability and so on. All of these abilities are essential for future sports teachers, students in physical education major.

\section{Cultivation Mode of Physical Education Practical Ability}

Through consulting China CNKI a great deal, Wanfang database and Baibu Baike's treatise, we learnt that scholars mainly studies physical education practical ability cultivation from concept and classification of cultivation mode and improvement mechanism of practical ability cultivation mode.

Firstly, there are studies on cultivation mode's concept and classification as follows:

Yajun Shi thought that cultivation mode referred to cultivation plan that school drew up in talents cultivation process in accordance with social environment, conditions and education policies. Wenju Cai pointed out that cultivation mode was specific expression form and realization mean of cultivation objective. It was a system project, including implementation of teaching concept, design of course and specific mean of teaching and so on. 
However, there was drawback in Chinese universities' mode of students' cultivation. For instance, cultivation objective on students was single, various schools showed the same cultivation mode, causing no individualism in Chinese universities' talents cultivation that may not satisfy various social demands (Zhang, 2008). This led to talents expansion in single aspect and deficient in diversified aspects. Yue Zhang thought that there were two cultivation modes, one was previous set cultivation method and mode, the other is management in cultivation process etc.

There were studies on improved mechanism of practical ability's cultivation mode:

Ailian Fang put forward mode of "whole process practical teaching", pointed out that fostering students' practical ability should be integrated into the entire teaching. Four-year University system was divided into eight terms. Then, from the 1st to 5th term, when teaching students' theory, we should also focus on exercises of practical ability, integrating practice into classroom, letting students' theoretical practice to develop together. Starting from the 6th term, we should lay more emphasis on fostering students' practical ability, as students' theoretical level arrived at certain requirements by the theoretical learning in the former five terms. At this time, we should let students walk out school and take practical exercises from multiple aspects, for instance taking trial teaching and so on. Starting from the 7th term, we should let students to teach independently, that is carrying out teaching practice. The key in the 8 th term is to write thesis. In this way, students can be exercises theoretically and timely in every time frame, instead of concentrating knowledge cultivation of practical ability on one time frame. Hongge Wu put forward in the mode of practical ability cultivation of students in physical education major : firstly school should make reasonable allocation on courses, formulate reasonable teaching objectives; secondly, students should make clear tasks and objectives of learning during learning, and then school should organize students to perform internship inside and outside school as much as possible in every term, participate in more professional teachers' open courses; besides, they should encourage students to take initiative in sports fitness activities; and school should make preparation of internship completely and do a good job in summarization and examination of internship.

Knowledge is not the sum of fact and rules by a kind of dynamic establishment and organization, and meanwhile it should be ability of individual coordinating behaviors and adapting to dynamic changes and developed environment. Students in physical education major of normal colleges should not only learn to take in knowledge but also promote individual practicability.

Fostering students' practical ability is a huge and complicated project and should run through the whole teaching process. School should constantly optimize teaching contents, pursue and explore new knowledge in accordance with social demands. Besides, it should also make reformation and innovation on the previous teaching methods and means, constantly improve theoretical level and practical ability. The school should lay emphasis on classroom teaching practice, go deeper into concept of connecting theory with practice, guiding students to apply learnt knowledge to solve realistic problems smoothly, combining inside with outside classroom and extending function of classroom teaching; besides, they should establish perfect education internship mechanism so that foster students' practical ability. They should adopt strict and effective examination system.

\section{RESEARCH OBJECTS AND METHODS}

\section{Research Objects}

Students in school physical education major in Grade 2013 to 2016. 
Table 1. Table of questionnaire releasing situation

\begin{tabular}{cccc}
\hline Total released questionnaire & Recovered questionnaire & Recovering rate of questionnaire & Valid rate of questionnaire \\
\hline 200 pieces & 186 pieces & $93 \%$ & $93 \%$
\end{tabular}

Research Methods

\section{Literature consultation}

According to defined research objects, tasks and purposes in this paper, we collect and read a lot of relevant treatise through CNKI, Wanfang database, Baidu Baike and so on, sort out and analyze all consulted documents to provide firm theoretical basis for the development of the research.

\section{Questionnaire Survey}

In this paper, questionnaire of "Questionnaire survey on students' practical ability cultivation status" was designed, 50 students were taken at random from all grades in physical education major from Grade 2013 to 2016 and released, that investigation was made to 200 students. Details can be referred to Table $\mathbf{1}$ as follows.

Questionnaire validity test: four experts were invited to carry out validity and structural test to ensure effectiveness of questionnaire. Results are three experts think that setting of the questionnaire is very reasonable, while the other thought it reasonable. This suggests the attached research questionnaire is valid.

Questionnaire reliability test: Firstly sample ten classmates to fill out questionnaire at random before releasing questionnaire in a big scale to ensure reliability of questionnaire. After ten days, these ten classmates were arranged to fill in the same questionnaire again. We found that the filling situation was roughly similar in two questionnaire, students relevant coefficient was $\mathrm{R}=0.87$, indicating the questionnaire had higher reliability.

\section{Mathematical statistics}

Make statistics of investigation data through Excel in computer.

\section{Logistic analysis}

Carry out logical analysis of students' practical ability status and cultivation mode constitute of physical education talents in accordance with the demands of investigation result, striving for providing references for fostering practical ability of physical education major.

\section{Interview method}

Perform interviewing with partial students and teachers in physical education major on relevant problems according to requirement of investigation, so that acquire certain information to create certain practical value for the research.

\section{CULTIVATION MODE OF STUDENTS' PRACTICAL ABILITY \\ Teaching Plan \\ Professional training objective and requirements}

Physical education institute fosters integrated talents, who are equipped with modern education and physical education's basic theoretical knowledge, capable of working in physical education, extracurricular sports training and competition arrangement, physical education science studying, school sports management and of creative spirits. 
Table 2. Constitute of class hour and credit in various courses

\begin{tabular}{cccc}
\hline & Type of courses & \multirow{2}{*}{ Total class hour and credit } & \multicolumn{1}{c}{ Due total credit - } \\
\cline { 2 - 4 } & General education course & $\mathbf{6 5 6 + 2}$ weeks /42 & $\mathbf{2 6 . 7 5 \%}$ \\
\hline \multirow{2}{*}{$\begin{array}{c}\text { Professional } \\
\text { basic course }\end{array}$} & Professional basic theoretical course & $606.8 / 39.3$ & $25.04 \%$ \\
\cline { 2 - 4 } $\begin{array}{c}\text { Professional } \\
\text { course }\end{array}$ & Professional basic experimental course & $311.2 / 18.7$ & $11.91 \%$ \\
\cline { 2 - 4 } & Profession-oriented theory course & $464 / 29$ & $18.47 \%$ \\
\hline & Profession-oriented experimental course & $192 / 12$ & $7.64 \%$ \\
\hline
\end{tabular}

Students in physical education major mainly learn basic theory and knowledge in school physical education, accept essential sports skill training as a sports teacher, and master basic ability of physical education, training, competition and scientific research.

\section{Study duration, graduate credit and degrees conferred}

Undergraduate in physical education major of physical education institute basically takes four year learning, and is allowed to graduate only get full 157 credits as required. In case that he conforms to conditions of degree when graduating, he would be conferred with bachelor degree.

\section{Curriculum setting}

According to talents cultivation plan, total disciplines of courses in physical education are 59 , from which there are 14 general courses, 18 required courses, 9 major courses and 28 elective courses. This indicates wider coverage of course in institute with a variety of forms. The institute attaches great attention to various aspects of students, and performs overall development on students' theory and practice.

In school's cultivation of students in physical education major, it highlights fostering students' stronger physical education practical ability. This indicates school focuses on students' practical ability cultivation. As shown in Table 2, credit in theory accounts for $70.26 \%$ of the total credit, and that in practical accounts for $29.72 \%$. This reflects that school relatively focuses on students' practical ability cultivation, which not only reflects in credit, but also in theoretical course as theoretical course builds foundation for practical course. With certain basic theory, practice could be implemented with facility.

\section{STUDENTS' PRACTICAL ABILITY STATUS}

\section{Students' General Practical Ability Status}

Statistical data shows that students' social practical ability and adaptability are increasingly enhancing with continuous learning, however, they don't show a significant increase in the improvement of other aspects. As students constant learn from kindergarten to university, they are rather satisfied with personal learning ability and expressions.

On a whole, students show higher satisfaction with their social practical ability in Grade 13 to Grade 16. They have improved adaptability as time goes by. However, there is a long way to go to develop their abilities in other aspects, especially the cultural and artistic ability and organization management ability that hasn't changed in four learning years of University.

\section{Status of Sports Teaching Ability of Students in Physical Education Major}

From statistical data, there is an increase in students' various ability on a whole as time goes by, from which the most significant increase lies in junior and senior year, especially reflecting in their ability of making teaching plans and applying textbooks. Reasons for that are school arranges students to take trial teaching and substitute teaching since junior year, and students in senior year would greatly improve their ability due to 
implementation of internship. However, the students should improve their resilience and ability of electronic education. Through interviewing and investigation, we found that our students haven't fully mastered physical and psychological characteristics of teaching objects in the stage of internship, leading to their poor handling with emergency. By observation and interviewing, we found that in the investigation on students' attitude towards internship, $41 \%$ of them thought that internship was very important, $35 \%$ of them thought it important, while $20 \%$ students just wanted to fulfill internship, and even $4 \%$ ones thought internship was just getting through formality and not important. This suggested that most of the students stressed on internship. Students showed an overall good internship performance in school, they took enough internship class in the whole process; $25 \%$ students reflected that they lacked of teachers' guidance in the internship process, most of them started to take over teaching in several classes after viewing and emulating teachers' lecturing for two weeks; in teaching, they just gave a lesson with personal feeling, lacking of guidance on lecturing. 10\% students reflected that their internship position didn't conform to their future work; some students didn't plan to teach but still took internship practice that was of no help. Some students planned to teach in middle school after graduation, but they took internship in primary school, there were certain gaps. Some students even expressed that they could not teach when started teaching in real situation, might not organize a physical education course, though they initially thought teaching was easy. They didn't know how to give a good lesson even though they were equipped with teaching skills and ability.

\section{Status of Sports Competition Organization Ability of Student in Physical Education Major}

From statistical data, freshman was weak in various abilities of sports competition since they just got into the school, and ability was under $20 \%$. With increasingly learning, improvement was made in diversified abilities, from which referee ability was most significant, while others were less and even the ability of summarizing competition accounted for the minimum. Investigation found that most causes of students' sports competition organization ability's improvement were because of participation in examination of national referee grade and engagement in referee, and such participation was for future development. On a whole, students' sports competition organization ability improved at various levels as time goes by. This is a good tendency.

\section{Status of Extracurricular Activity Ability of Students in Physical Education Major}

From statistical data, students have improved extracurricular activity ability at various levels as time goes by and shown an overall increase trend, especially the most increasing amplitude in organizing class leagues. This suggested that students have learnt a lot in extracurricular activity ability, basically applied what they learnt.

\section{Status of Sports Training Ability of Students in Physical Education Major}

From statistical data, having learnt a series of sports knowledge and professional skills, students have improved sports training ability in all aspects. Especially, junior and senior students' ability is generally superior to that of freshman and sophomore. There are improvement of ability "application of sports training methods and means" in sophomore and junior year at various degrees, while the improvement is not significant in senior year.

By investigation, many students only simply learn skills but ignore importance of theory in skill course; they may not well combine theory with practice and further lead to mistakes in future teaching.

\section{Status of Scientific Research Ability of Students in Physical Education Major}

By questionnaire survey, it shows scientific research ability contains ability of selecting topics, ability of document retrieval, ability of scientific research method, ability of writing thesis, ability of finding problems. Among students in physical education institute, generally only senior students possess scientific research ability, with an exception of less junior students, whereas freshman, sophomore and most of junior students haven't got involved in thesis, and they are weak in scientific research ability. Carry out questionnaire survey on senior students, found that $9 \%$ students realized the important of thesis and would write it in earnest, $23 \%$ ones thought it important, $55 \%$ ones regarded it as general and just wanted to fulfill thesis defense, even $13 \%$ ones thought it not 
important and no more than a form. It is clear that students don't pay enough attention to thesis comparing to internship. Through investigation on thesis advisers, students by interviewing and problems in students thesis preparation process, we found that $70 \%$ students supposed that they lacked of scientific research theoretical knowledge, not knowing how to writer personal thesis, 55\% ones thought they lacked of teachers' guidance in writing process as the teachers were too busy to spend enough time in guiding their writing. The opening time of students' thesis generally starts from the beginning of the 7th term summary vacation to the starting of the 8th term. However, due to topic selection starts in vacation, students are not available to access to CNKI to consult data, they lack of learning enthusiasm as in school and don't select it. While they should start internship right now since school starts, they basically have no time to write thesis. In addition, they tend to forget relevant thesis research problems after internship, together with tight job hunting period during the second time of senior year, they lack of writing duration and guidance.

From the above status of six practical abilities, from students' practical ability status investigation result, we learnt that freshman was slightly poor in practical ability of all aspects as they just enter into school. Sophomore has some improvement in abilities through around one year's learning, but their abilities are not mature. Junior students have improved various abilities after over two years' university life, their ability in various aspects are overall nearly similar to that of senior students, whereas the senior students have somewhat improvement in the mature degree through education internship by comparing. Therefore, status of senior students' practical ability can be a good reflection of current students' practical ability cultivation status in physical education major.

\section{CONCLUSIONS}

Research on status of practical ability cultivation of students in physical education major and get three conclusions as follows:

i) Cultivation mode of undergraduate includes teaching plan, management system, comprehensive evaluation, practical teaching. In teaching plan of physical education, students' practical ability cultivation was fully represented; Students' practical teaching covers sports theoretical knowledge and skill practical teaching, cultivation of extracurricular activities' practical ability, internship practice and thesis.

ii) There are two main braches and six parts in evaluation indicators of practical ability of undergraduate in physical education major, such as general practical ability and special practical ability, the later one includes sports knowledge and skill, sports training ability, sports competition organization ability, extracurricular activities' organization ability and scientific research ability. Students major in physical education have shown a rising trend in various practical abilities as they upgrade, from which they have higher grasping of sports teaching ability, sports training ability and sports competition organization ability, whereas they are weak in general practical ability, such as organization management ability, sports competition organization ability and extracurricular activities' organization. They should improve scientific research ability. They show an overall good internship situation, but lack of theoretical knowledge in writing thesis and teachers' guidance.

iii) The undergraduate major in physical education could improve their practical ability from four aspects: strengthening their practical ability in sports knowledge and sports skill teaching, sports competition organization ability, external-campus practice base's construction as well as guidance on scientific research ability.

\section{SUGGESTIONS AND STRATEGIES}

\section{Strengthen Physical Education Knowledge and Skills' Practical Ability Teaching}

In current Chinese university students' cultivation process, there are two parts of students in schoolattending a class and extracurricular activities. Among them, most of the students' professional knowledge learning 
still bases on class learning. As far as students in physical education major, there are two parts in physical education major's teaching, one is teaching of sports knowledge, the other is classroom teaching of sports skills. Thus, teaching of sports knowledge and skills cover a great part in the overall students' professional learning. It is crucial to promote sports knowledge and skills' practical ability teaching.

Firstly, in the regard of sports knowledge teaching, sports exercises are closely related to sports teaching in many theoretical courses of sports. When preaching theoretical knowledge, the teacher should teach theory and also combine the theoretical knowledge with practical sports. In teaching, teachers should play the guiding role, center on students, guide students to initiatively find problems, think problems and further solve them. They should apply more discussion teaching to arouse students' learning interests.

Secondly, in the process of teaching sports skill course, teacher would instruct students' skill movements to enable them to master movement skills basically, but also enable them to master how to teach the skill movements. In class, they should train students' teaching ability, let students to carry out warm-up or skill movements' revision in turn, or assign them certain teaching tasks, let students to complete simulation teaching in one class independently. And in skill examination, teacher should not only examine students' skill movements, but also get involved in examining students' grasping of theoretical knowledge and their practical teaching.

\section{Strengthen Organization of Sports Competitions}

In investigation on status of practical ability of students in physical education major, we found that they have great deficiency in the ability of organizing sports competitions. Every year, physical education institute organizes some sports competition activities to improve students' sports ability and competition ability, such as organizing sports meeting, Huanggang Normal College's Cup, football league and so on. Through exchanging with students, we found that most of them focused on these competitions, consciously organized training before competition to enhance sports skills.

Organization on these competitions, however, is far from enough by comparing. We should properly increase students' participation times in sports competitions to enhance their ability of sports competition. Above all, changes in quality results from that in quantity.

\section{Strengthen Construction of External-campus Practice Base}

External-campus practice base is precondition of students' practical teaching. Only with stable externalcampus practice base, the schools' implementation of practical teaching could then be ensured. School should make use of social resources, and optimize them. Generally, students would go to work after graduation. The construction of practice base not only can give guidance on society and school regarding the demands of talents, but also offer a real job for students who would graduate, letting them to get into society in advance and adapt to the society. Internship is an examination on students' knowledge and skills and also a performance in working ahead of time. For students in physical education major, they are mainly working as a teacher in school after graduation. In selecting external-campus practice base, there should firstly be equipped with practice bases with high quality, stable and fixed amounts. At present, due to lack of practice bases, many universities would arrange over 10 students in one practice base. The scale of practice base school is fixed with enough formal teachers, students would have nothing to do and lack of practicing opportunity if too many ones are assigned to one practice base. Besides, school should strengthen communication with practice base, guarantee for students' exercising opportunities during internship and increase guidance on students' internship so on.

\section{Strengthen Guidance on Ability of Writing Thesis}

For cultivation of ability of writing thesis, physical education institute has attached great important. It issued various documents on thesis management; there were normalized management from students' thesis subject selection to defence. However, in the real implementation process, many people think scientific research ability is 
not so important for students; thesis is just a form as required. As students confront with an important task as finding a job after graduation, they don't focus on writing a thesis and some of them copy thesis.

For students' thesis, both schools and advisors should attach great emphasis, they could increase cultivation of students' scientific research ability from freshman to junior year, for instance, reinforcing researching lectures, organizing more subject researches, encouraging students to positively participate in and so on. Guiding on thesis could also follow master's advisor system, thesis advisors would be assigned to students after starting school for a while. The advisers could guide students in certain time and duration every term. We also suggest that school to make proper adjustment on physical education talents cultivation plan in accordance with social realistic conditions.

\section{ACKNOWLEDGEMENTS}

Key Discipline Construction Project of Longyan University in 2016.

\section{REFERENCES}

Chen, C., \& Zhang, B. (2016). Factor analysis in optimizing the structure of the sports industry. In: Z. Henan and J.Y. Beijing, eds. 2016 National Convention on Sports Science of China, Zhengzhou China, SEP 23-25 2016. France: EDP Sciences. doi:10.1051/ncssc/201701013

Li, F., Liu, L., Wang, Q. H., Qin, K. L., Hu, Q. Q., Yang, Q., Liu, Y. N., \& Zhang, B. (2016). Tennis balls judgment model based on numerical simulation. In: Z. Henan and J.Y. Beijing, eds. 2016 National Convention on Sports Science of China, Zhengzhou China, SEP 23-25 2016. France: EDP Sciences. doi:10.1051/ncssc/201701018

Li, X. P., Xu, M. H., Zhao, F. N., Zhang, L., \& Zhang, G. Z. (2017). Research on the Construction of Ecological System of Internet Learning Resources for Postgraduates. Academic Degrees E Graduate Education, (4), 26-30. doi:10.16750/j.adge.2017.04.006

Liu, Y. (2013). Public Service Supply Mode Transformation and Realistic Choice Since 30 Years of Reform and Opening up in China. China Sport Science, 33(02), 11-21. doi:10.16469/j.css.2013.02.006

Zhang, B. (2017). Research on the Development and Change of Chinese Sports Science Based on Bibliometric Analysis. Eurasia Journal of Mathematics Science and Technology Education, 13(10), 6407-6414. doi:10.12973/eurasia.2017.01073a

Zhang, B., \& Peng, P. (2017). Research on the Development of Education Resources for the Internet Plus Universities in the National Health Field. Eurasia Journal of Mathematics Science and Technology Education, 13(8), 50855093. doi:10.12973/eurasia.2017.00984a

Zhang, B., \& Qin, K. L. (2016). Chinese ski sports tourism development research under grey model. In: Z. Henan and J.Y. Beijing, eds. 2016 National Convention on Sports Science of China, Zhengzhou China, SEP 23-25 2016. France: EDP Sciences. doi:10.1051/ncssc/201701054

Zhang, B., \& Qin, X. P. (2012). “Use money to buy service”: new ideas for sports basic public service provision mechanism. Journal of Shandong Institute of Physical Education and Sports, 28(5), 6-10. doi:10.3969/j.issn.10062076.2012.05.002

Zhang, Y. J. (2008). On the Influencing Factors and Countermeasures of Sustainable Development of Track and Field Event in Beijing. Journal of Capital College of Physical Education, 20(2), 38-41. doi:10.3969/j.issn.1009783X.2008.02.011

Zhou, T., Zhang, F. H., \& Su, Z. N. (2012). The United States and Britain and Japan City Community Sport Public Service Construction Experience and Its Enlightenment to China. Sports \& Science, (04), 69-74. doi:10.3969/j.issn.1004-4590.2012.04.017

\section{http://www.ejmste.com}

